\title{
PLURALISME DAN RADIKALISME MUSLIM MASYARAKAT TRANSISI: EKSPRESI KEBERAGAMAAN DI KAWASAN INDUSTRI KABUPATEN BEKASI
}

\author{
Ridwan Rosdiawan
}

\begin{abstract}
Abstraks
Kawasan industry Kabupaten Bekasi dipilih sebagai sampel karena karakternya yang khas. Kehidupan tipe masyarakat pedesaan beralih secara cepat menuju tipe masyarakat perkotaan akibat industrialisasi. Adapun topic ekspresi keberagamaan yang dipilih adalah pluralism dan radikalisme dari masyarakat Muslim yang berdomisili di

kawasan tersebut. Penentuan fokus masyarakat Muslim dilatarbelakangi oleh rasionalisasi bahwa mereka adalah penduduk dominan yang paling mewarnai kehidupan sosial di sekitarnya. Dengan menggunakan teknik penelitian lapangan melalui pengumpulan data berdasarkan observasi, wawancara dan kuesioner, penelitian ini diarahkan untuk mengklarifikasi fokus penelitian yang diformulasikan dalam bentuk pertanyaan: Bagaimanakah transisi kehidupan sosial akibat industrialisasi berkontribusi terhadap pluralism dan radikalisme masyarakat Muslim Kabupaten Bekasi?

Dengan menafsirkan data melalui pendekatan deskriptif-analitis, penelitian ini menemukan bahwa transisi akibat industrialisasi memang sangat berpengaruh terhadap sikap pluralism masyarakat Muslim. Namun, pluralism itu masih sangat datar dan dangkal

(superficial) sehingga sangat mungkin seketika berubah radikal seiring berubahnya kondisi-kondisi umum di sekitar.
\end{abstract}

Kata Kunci: Pluralisme, Radikalisme, Muslim

\section{Pendahuluan}

Agama dan Etnisitas merupakan dua aspek penting yang mempengaruhi dinamika hubungan sosial di Indonesia. Berbagai konflik pasca runtuhnya Orde Baru yang menyebabkan puluhan ribu meninggal dan ratusan ribu lainnya mengungsi ke berbagai wilayah di Indonesia yang lebih aman juga melibatkan unsur agama dan atau etnis. Keterlibatan etnis Madura dan Dayak di Kalimantan Barat, Muslim dan Kristen di
Maluku dan Poso adalah diantara sejarah kelam hubungan sosial yang kental dengan semangat etnisitas dan agama. Ekspresi atas etnisitas dan agama diatur secara ketat pada masa Orde Baru dengan berbagai regulasi dan gerakan politik menyebabkan terpendamnya berbagai rasa dendam, kekecewaan dan diskriminasi. Saat itu, partai politik penguasa dan tentara memainkan peran sangat kuat dalam upaya memprioritaskan kebijakan negara, yaitu 
pertumbuhan ekonomi, dan mengabaikan pertumbuhan kultural. Akibatnya kemajuan ekonomi tidak dibarengi dengan fondasi kultural yang mapan. Kebijakan negara yang berorientasi pertumbuhan ekonomi tidak dirasakan secara merata. Karena itu, sikap antiminoritas sangat kental. Diantaranya adalah anti Tionghoa dan anti Kristen.

Beberapa peristiwa anti Tionghoa terjadi pada akhir dekade Orde Baru, yaitu pada 1996 di Situbondo dan Tasikmalaya. Gejala yang sama juga terjadi di Kabupaten Bekasi, bagaimana dinamika hubungan sosial sangat rentan akibat kebijakan negara dan tumbuhnya kelompok yang memainkan semangat agama dan etnisitas. Masyarakat Kabupaten Bekasi adalah prototipe masyarakat Indonesia yang plural baik etnis, agama maupun budaya. Beberapa tradisi berkembang di daerah ini dengan latar belakang agama: Islam, Kristen, Hindu, Budha, Konghuchu. Dua komunitas yang dominan yaitu Islam dan Kristen. Dalam umat Islam sendiri terdapat banyak ideologi yang berkembang: (1) Islam radikal, yang dipelopori oleh Front Pembela Islam. (2) Islam moderat, yang dipelopori oleh jaringan pesantren Nahdatul Ulama dan Muhammadiyah. Kedua organisasi Muslim terbesar di Indonesia ini memiliki basis komunitasnya sendiri di kabupaten ini. (3) Islam abangan, yang secara KTP beridentitas Islam, tetapi dalam praktik sehari-hari melakukan tradisi dan ritual agama Jawa, yang dekat dengan budaya Hindu-Budha.

$\begin{array}{ccc}\text { Tulisan } & \text { ini } & \text { mencoba } \\ \text { mengeksplorasi } & \text { pola } & \text { kehidupan } \\ \text { keberagamaan } & \text { masyarakat } & \text { Kabupaten }\end{array}$
Bekasi dari dua sisi. Pertama, menyisir potensi tingkat militansi dan radikalisasi pandangan keberagamaan yang terbentuk. Kedua, memetakan pandangan-pandangan pluralism serta kemungkinan potensi konflik dan integrasi sosial di tengah masyarakat. Beberapa studi pustaka juga digunakan sebagai alat analisis korespondensi dengan tujuan menerjemahkan fenomena-fenomena sosial tersebut pada ranah teoritis.

\section{Profil Singkat Masyarakat Kab. Bekasi}

Kabupaten Bekasi merupakan bagian dari Provinsi Jawa Barat dengan ibukota di Cikarang Pusat. Kabupaten Bekasi terdiri dari 23 kecamatan, yang dibagi lagi atas sejumlah desa dan kelurahan. Kabupaten Bekasi memiliki luas wilayah $1.273,88 \mathrm{~km}^{2}$ yang terdiri dari 23 Kecamatan dan 182 desa serta 5 kelurahan. Jumlah desa yang terdapat disetiap kecamatan di Kabupaten Bekasi terdiri dari 5 sampai 13 desa. Kecamatan dengan jumlah desa yang paling sedikit yaitu kecamatan Cikarang Pusat, sedangkan kecamatan yang memiliki jumlah desa terbanyak adalah Kecamatan Pebayuran. 
Dengan penduduk berjumlah sekitar 2.270.900 orang, sejak beberapa tahun Kabupaten Bekasi terus mengembangkan dan mempromisikan dirinya sebagai daerah industri. Pada tahun 2001, misalnya, dengan jumlah 595 perusahaan yang bergerak di segala bidang, saat ini Kabupaten Bekasi merupakan kawasan industri terbesar di Indonesia yang mampu menyerap tenaga kerja dari berbagai daerah hingga mencapai 666.580 tenaga kerja. ${ }^{1}$ Sejak 1980-an kemajuan industrialisasi yang berkembang pesat di Kabupaten Bekasi menjadi babak baru bagi sejarah masyarakat yang masih kuat memegang norma-norma dan tradisi masyarakar agraris. Untuk menopang dan mempercepat visi sebagai daerah industri yang religius, "Masyarakat Agamis Berbasis Agrobisnis dan Ekonomi Berkelanjutan", saat ini Kabupaten Bekasi telah memiliki tiga kawasan raksasa industri yang umumnya tersebar di bagian selatan, EJIP (East Jakarta Industrial Park), Jababeka, dan Kawasan Industri Cibitung 2100. Belum lagi kawasankawasan kecil industri lainnya yang sebagian besar terletak di pinggiran kota. Pertumbuhan ini sudah barang tentu melahirkan gelombang lapangan kerja yang sangat besar sehingga bisa menyedot masyarakat dari seluruh

\footnotetext{
Lapangan usaha terdiri dari pertambangan, industri, listrik, gas, air minum, bangunan dan konstruksi, perdagangan, hotel, restoran, angkutan
}

Indonesia yang ingin mengadu nasib di daerah ini. Secara selintas, pertumbuhan ekonomi pun mengalami kenaikan yang cukup pesat hingga mencapai Produk Domestik Regional Bruto (PDRB) tahun 2001 sebesar 32,28 trilyun dengan kontribusi terbesar di sektor industri sebesar $83,48 \%$.

\section{Radikalisme di Kab. Bekasi}

Radikalisasi masyarakat Kabupaten Bekasi dalam rentang lebih dari tiga abad sejarah meliputi beberapa konteks, yang memiliki latar belakang berbeda sehingga interpretasi atas kekerasan yang ditimbulkan juga beragam. Umumnya radikalisasi memiliki keterkaitan dekat dengan ekonomi dan politik, yang bisa terjadi di belahan wilayah Nusantara lainnya. Berbagai 'pemberontakan' yang dilakukan oleh beberapa gerakan pada masa kolonial Belanda yang kerap terjadi akibat kebijakan kolonial yang memojokkan ekonomi rakyat. Setidaknya terdapat tiga kecenderungan radikalisasi. Pertama, kekerasan yang muncul akibat ekspresi ketidakpuasan dan kekecewaan masyarakat atas kebijakan penguasa, baik politik maupun ekonomi yang tidak berpihak pada kepentingan masyarakat bawah. Kedua, terjadi kesenjangan komunikasi antara lapisan elit dan

dan komunikasi, keuangan, persewaan dan jasa perusahaan. Badan Pusat Statistik (BPS) Kabupaten Bekasi Tahun 2001. 
masyarakat umum, sehingga keputusan pemerintah pusat dianggap bertentangan dengan logika masyarakat lokal. Ketiga, ideologi yang berkembang baik berbasis agama maupun politik membentuk komunitas radikal. Kelompok ketiga ini adalah bagian dari gerakan laten yang naik turun sesuai dengan perkembangan politik lokal dan nasional.

Munculnya gerakan radikal berbasis agama ini menurut Scott Appleby sebagai ekspresi atas "Kemarahan Sakral' melawan diskriminasi rasial, etnis dan agama; ketidakadilan kebijakan ekonomi ..., korupsi dan hipokritas dalam pemerintah; kebijakan negara atau swasta ..., kekerasan sistematis dan keamanan." Imam Samudra menyatakan bahwa Bom Bali, 12 Oktober 2002 adalah bagian dari ekspresi balasan bagi Barat, khususnya Amerika Serikat dan beberapa sekutunya, yang dianggap menghancurkan eksistensi Islam di Afganistan, Palestina, dan wilayah lain. Tetapi berdirinya beberapa laskar dan milisi Islam untuk dikirim ke daerah konflik di Maluku dan Poso, Sulawesi Tengah, memiliki alasan berbeda, yaitu membantu masyarakat Muslim yang dianggap terdesak oleh tekanan pasukan Kristen, dan tidak melihat pasukan keamanan negara tidak melindungi masyarakat Islam.

2 Budhy Munawar-Rachman, Ensiklopedi Nurcholish Madjid, Jld. I (Jakarta:

Paramadina-Mizan-CSL, 2006), h. H. 724.
Seiring dengan perkembangan industrialisasi ini, gejala-gejala sosialpsikologis sebagai akibat perubahan yang sangat cepat dapat dimanipulasi dengan mudah untuk tujuan-tujuan tertentu. Hal ini disebabkan karena gejala-gejala ini dengan sendirinya diikuti dengan perasaan kecewa, dendam, dan keinginan emosional untuk melawan "kemapanan" (establishment).

Kemapanan di sini bisaanya dianologikan dengan pemerintah dan kelompok elit penguasa (ruling elite). Namun, gejala-gejala tersebut dapat memotivasi timbulnya inisiatif dalam mencari faktor pengimbang dan kompensasi. Pencarian faktor pengimbang ini biasanya disalurkan dalam dua bentuk, baik negatif maupun positif. Contoh dari pengimbang yang negatif adalah munculnya sikap-sikap radikal yang sering dijadikan mediator untuk "mengisi" kekecewaan dan ketidakpuasan tersebut. ${ }^{2}$ Bahkan dalam pandangan Morris Janowitz, dampak dari perubahan sosial tersebut adalah adanya prasangka atau stereotype yang cenderung destruktif dan penuh dengan stigma mengenai kelompok atau golongan tertentu, sehingga sulit menunjang terjadinya proses perubahan sosial yang positif menuju demokrasi dan pluralisme. $^{3}$

3 Ibid., Jld. II, h. 800. 
Secara antropologis, masyarakat Kabupaten Bekasi sendiri, sebenarnyameminjam istilah Alvin Toffler-adalah masyarakat yang masih berada dalam dua gelombang (wave) pertama peradaban umat manusia, yakni pertanian dan industri. Secara geografis, masyarakat Bekasi bagian utara adalah bermata pencaharian sebagai petani yang jauh tertinggal pembangunannya dengan daerah selatan sebagai pusat industrialisasi. Sedang bagian selatan adalah daerah kawasan industri yang selama ini dianggap sebagai daerah serapan air masyarakat daerah Bekasi bagian utara. ${ }^{4}$ Permasalahan ini semakin kompleks seiring dengan belum terbangunnya tatanan nilai sebagai masyarakat industri atau modern bagi sebagian besar masyarakat Bekasi. Artinya, pembangunan secara fisik tidak bisa diikuti dengan perkembangan pandangan dunia-nya yang masih sangat tradisional. Modernisasi atau industrialisasi yang terjadi hanya pada bangunan fisik, sedang kesadaran dan pandangan dunia (worldview) sebagai masyarakat tradisional yang memiliki ciriciri paguyuban, mistifikasi beragama, dan semangat patron-client yang kuat, masing dipegang sebagai kesadaran hidup.

Dalam hubungan ini, terdapat beberapa kerangka pemikiran yang

4 Badan Pusat Statistik (BPS) Kabupaten Bekasi Tahun 2001.

5 Mulyana, W. Kusuma, "Analisis Sosial tentang Kerusuhan Massa Kasus Pemilu menarik untuk ditelaah sebagai analisis sosial terhadap permasalahan radikalisme. Prof. Dr. Usman Pelly, mantan guru besar Antropologi IKIP Medan, mengemukakan mengenai adanya tiga sumber konflik dalam masyarakat. Pertama, perebutan sumber daya, alat-alat produksi dan kesempatan ekonomi; kedua, perluasan batas-batas kelompok etnis dan sosial-budaya; serta ketiga, perbenturan kepentingan politik, ideologi dan agama. Ketiganya lebih banyak didapati dalam masyarakat perkotaan atau masyarakat majemuk yang mulai tumbuh karena perkembangan industri yang pesat dibandingkan dengan masyarakat pedesaan. Intensitas konflik dengan faktor-faktor kemajemukan masyarakat dapat diklasifikasikan ke dalam dua kategori, yakni horisontal dan vertikal. Faktor-faktor horisontal meliputi etnis/ras atau asal-usul keturunan; bahasa daerah; adat istiadat; agama; dan kehidupan sosial-politik. ${ }^{5}$ Apabila kemajemukan horisontal merupakan ascribed factors, sedang faktor-faktor kemajemukan vertikal lebih banyak berciri achievement factors.

Permasalahan tersebut berujung pada kesadaran masyarakat sebagai masyarakat yang tertindas (oppressed society). Tertindas dari perkembangan globalisasi yang mewujud dalam bentuk

1997", dalam Ahmad Suaedy (ed.), Kekerasan dalam Perspektif Pesantren, (Jakarta: Grasindo-P3M, 2000), h. 71. 
hegemoni industri yang kurang memperhatikan aspek lokalitas masyarakat dan lebih mementingkan etnis dan agama tertentu. Nampaknya prejudice atau kecurigaan masyarakat pada industrialisasi memuncak ketika Pengelola Kawasan Jababeka membangun rumah ibadah bagi umat Kristiani, pembangunan gereja di beberapa kompleks perumahan elit seperti Lippocity Cikarang, perumahan Legenda di Tambun Utara. Sebaliknya, di sejumlah perumahan yang mayoritas penduduknya adalah Non-Muslim, maka pembangunan masjid dan musholla pun mendapatkan perlawanan yang sama. Dalam konteks ini, nampaknya cukup relevan ketika Kuntowijoyo mengatakan bahwa masyarakat yang bekerja di sektor industri atau nonpertanian itulah yang apabila persoalan, seperti pengangguran atau penghinaan, mudah menjadi agresif emosional, punya collective behavior tanpa harus digerakkan pihak ketiga atau dikipasi. $^{6}$

Bentuk gagasan yang terdapat dalam konsep radikalisme ini bisa diterapkan untuk melihat gejala radikalisme sosial yang berkembang di daerah Kabupaten Bekasi lima tahun terakhir. Sebagai weltanshauung atau pandangan dunia (worldview) sekaligus pengalaman hidup (lebensew/t), radikalisme agama yang muncul dalam bentuk penolakan pembangunan rumah ibadah, nampaknya merupakan imbas dari pembangunanisme (developentalism) atau modernisasi yang belum selesai di Negara-negara miskin. Faktor marjinalisasi penduduk asli (baca: umat Islam) dalam merespon dan lemahnya pemerintah daerah dan investor asing maupun domestik yang kurang memaksimalkan perhatiannya pada community development, adalah faktor-faktor yang menimbulkan maraknya sikap radikalisme beragama di daerah industri ini.

\section{Pluralitas, Konflik dan Integrasi Sosial}

Sebagaimana banyak kota lain di Indonesia, Kabupaten Bekasi sangat diwarnai oleh pendatang. Romo Mardi menyebutkan bahwa masyarakat asli Bekasi sangat toleran dan reseptif atas segala agama, ideologi dan organisasi politik yang masuk. Mereka secara terbuka menerima setiap pengaruh positif. Karena itu, dimanika politik nasional banyak mendapat semangat awal dari kota ini. Misalnya, berdirinya Sarikat Islam pada 1912 menandai kebangkitan pergerakan dengan identitas agama dan etnis. Juga penggulingan Suharto pada 1998 mendapat sambutan hangat dengan gerakan anti Orde Baru. Keberagaman Kabupaten Bekasi tercermin dari meratanya organisasi dari

6 Mulyana, W. Kusuma, "Analisis Sosial..., ibid., h. 69. 
faksi Kiri ke faksi Kanan, kelompokkelompok Radikal, dan tumbuhnya organisasi masyarakat minoritas. Beberapa teori etnisitas akan menjadi landasan analisis atas fenomena hubungan sosial dan tradisi kekerasan di Bekasi. Teori pertama oleh C.W. Watson, yang menyatakan bahwa di kalangan cendekiawan multikulturalisme dianggap sebagai kebijakan untuk mencapai tatanan masyarakat di mana warga yang berasal dari berlain-lain agama, suku, adat, atau kebudayaan dapat hidup bersama-sama dan membaur dalam pergaulan sehari-hari dengan damai dan sejahtera tanpa mengorbankan ciri-ciri khasnya masing-masing. Malah akan diberi peluang sepenuh-penuhnya untuk mempertahankan adat dan tradisinya. Perlu ditegaskan bahwa kebijakan ini bertolak belakang dari kebijakan yang disebut assimilationism - usaha untuk mempersamakan semua kelompok dalam satu masyarakat - atau ideologi 'meltingpot' yang terkenal di AS zaman dulu di mana yang diharapkan ialah semua orang darimanapun mereka berasal - dari negera gunung atau kepulauan dekat laut - akan ketemu di kwali juga dan sesudah dikocok di sana akhirnya akan keluar sama semua. Multiculturalism beranggapan bahwa prinsip "melting-pot" ini ialah satu penghinaan karena seakanakan memaksa orang menanggalkan warisan dari leluhurnya yang diterima secara terhormat turun-temurun, dan menjadikan mereka manusia baru, seragam dengan warga yang lain.

Dengan mengacu pada Furnivall (1948), Parsudi Suparlan membedakan antara masyarakat plural dan masayrakat multicultural. Pada dasarnya masyarakat plural mengacu pada suatu tatanan masyarakat yang di dalamnya terdapat berbagai unsur masyarakat yang memiliki ciri-ciri budaya yang berbeda satu sama lain. Masing-masing unsur relatif hidup dalam dunianya sendiri-sendiri. Hubungan antarunsur yang membentuk masyarakat plural tersebut relatif lebih rendah dan terbatas. Hubungan antarunsur yang berbeda itu juga ditandai oleh corak hubungan yang dominatif, dan karenanya juga bersifat diskriminatif. Meski wujud konkritnya masih terlihat samarsamar, tatanan masyarakat multikultural yang hendak dituju cenderung mengacu pada suatu tatanan masyarakat yang unsur-unsurnya memiliki ciri yang juga beragam.

$$
\text { Perbedaan yang jelas }
$$

dibandingkan dengan masyarakat plural ialah dalam masyarakat multicultural terdapat interaksi yang aktif di antara unsur-unsurnya melalui proses belajar. Lebih dari itu, kedudukan berbagai unsur yang ada di dalam masyarakat itu berada dalam posisi yang setara, demi terciptanya keadilan di antara berbagai unsur yang saling berbeda.

Industrialisasi diberi definisi sebagai proses perkembangan teknologi 
melalui penggunaan ilmu pengetahuan terapan. Hal tersebut ditandai dengan ekspansi produksi besar-besaran melalui penggunaan tenaga permesinan, daerah pemasaran yang luas bagi barang-barang produsen maupun konsumen, angkatan kerja yang terspesialisasikan dengan pembagian kerja, dan urbanisasi yang meningkat. $^{7}$

Menyertai perubahan di bidang ekonomi adalah perubahan yang kompleks dalam kelompok dan proses sosial. Tahap pertama yang tipikal dalam proses industrialisasi, berdampingan dengan urbanisasi, adalah meningkatnya mobilitas penduduk, di samping adanya perubahan yang penting dalam adat kebisaaan dan moral masyarakat. Namun yang sangat menonjol adalah pengaruhpengaruh terhadap status pekerjaan dan keahlian-keahlian penduduk kerja, kehidupan keluarga dan kedudukan wanita, tradisi serta kebisaaan-kebisaaan dalam mengonsumsi barang. Konflik antarkelas, ras, agama dan kelompok sosial lainnya juga dilihat sebagai akibat penyerta yang tipikal.

Dengan demikian, industrialisasi menyangkut perubahan sosial, yakni perubahan susunan kemasyarakatan dari sistem sosial pra-industri (agraris) ke sistem sosial industrial. Kadang-kadang hal ini juga disejajarkan dengan perubahan dari masyarakat pramodern ke masyarakat modern. Atau, dalam istilah yang sering digunakan saat ini, perubahan dari "negara kurang maju" (less developed country) ke keadaan masyarakat "Negara yang lebih maju" (more developed country). Untuk itu, para ahli ilmu sosial membedakan hubunganhubungan "natural dan organis" keluarga, desa, dan kota kecil (gemeinschaft) dengan kondisi yang "artifisial" dan "terisolasi" dari kehidupan kota dan masyarakat industri (gesellschaft), ketika hubungan-hubungan asli dan natural manusia satu sama lainnya telah dikesampingkan, dan setiap orang berjuang untuk keuntungannya sendiri dalam semangat kompetisi. Menurut Bahtiar Effendi, pertemuan (encounters) masyarakat agama dengan realitas empiris tidak selalu mengambil bentuk wacana dialogis yang konstruktif. Alihalih, yang muncul adalah mitos-mitos ketakutan yang membentuk kesan bahwa perubahan sosial yang cepat itu dengan serta-merta menyebabkan agama berada pada posisi "bawah" (subordinate) atau "pinggir". Suatu pengalaman masyarakat Eropa Barat, yang dalam pandangan Ernest Gellner, "pertemuan" mereka dengan perkembangan ilmu-ilmu sosial dan industrialisasi mengantarkan mereka pada pintu "sekularisasi". Dengan itu,

\footnotetext{
7 Budhy Munawar-Rachman, Ensiklopedi..., Jld. II, op. cit., h. 1080.
} 
nilai-nilai agama dikhawatirkan memudar. $^{8}$

Bahkan sampai pada tingkat tertentu, masyarakat agama dewasa ini dihadapkan pada situasi kegamangan dalam menghadapi proses globalisasi. Kekhawatiran bahwa perkembangan teknologi dapat (a) meminggirkan nilainilai agama; (b) menghancurkan ikatan unit-unit sosial masyarakat; dan (c) pada akhirnya memisahkan agama dari dasardasar organisasinya. ${ }^{9}$ Inilah sistem nilai kompensasi masyarakat yang negatif yang melahirkan sikap radikalisme beragama di kalangan masyarakat bawah.

Istilah "radikalisme" sebenarnya bukan konsep asing dalam ilmu sosial. Disiplin politik, sosiologi, dan sejarah sejak lama telah menggunakan terma ini untuk menjelaskan fenomena sosial tertentu. Sejarawan Kartono Kartodirjo, misalnya, menggunakan istilah ini untuk menggambarkan gerakan protes petani yang menggunakan simbol agama dalam menolak seluruh aturan dan tatanan yang ada. Kata "radikal" digunakan sebagai indicator sikap penolakan total terhadap kondisi yang sedang berlangsung. ${ }^{10}$ Dalam konteks ini, Adeed Dawisha menggambarkan radikalisme sebagai sikap jiwa yang membawa kepada tindakan-tindakan yang bertujuan melemahkan dan mengubah tatanan politik mapan-dan bisaanya dengan cara-cara kekerasan-dan menggantinya dengan sistem baru. ${ }^{11}$

Mengadopsi temuan Horace $\mathrm{M}$. Kallen, radikalisme sosial sedikitnya memiliki tiga ciri mainstream dalam melakukan gerakannya. Pertama, radikalisme merupakan respons terhadap kondisi yang sedang berlangsung. Bisaanya respon tersebut muncul dalam bentuk evaluasi, penolakan atau bahkan perlawanan. Masalah-masalah yang ditolak berupa asumsi, ide, lembaga atau nilai-nilai yang dipandang bertanggungjawab terhadap kelangsungan kondisi yang ditolak. Kedua, radikalisme tidak berhenti pada upaya penolakan, melainkan terus berupaya mengganti tatanan tersebut dengan bentuk tatanan lain. Ciri ini menunjukkan bahwa di dalam radikalisme terkandung program atau pandangan

merupakan salah satu di antara berbagai instrument kebijakan para pelakunya, sedang "radikalisme" adalah esensi dari kebijaksanaan itu sendiri; radikalisme juga mencakup nilai-nilai, tujuan dan concern dari orang-orang yang merumuskan kebijaksanaan tersebut. Lihat Dr. Azyumardi Azra, Pergolakan Politik Islam: Dari Fundamentalisme, Modernisme hingga Postmodernisme (Jakarta: Paramadina, 1996), h. 147. 
dunia tersendiri. Dengan demikian, sesuai dengan arti kata "radic", sikap radikal mengandung keinginan untuk mengubah keadaan secara mendasar. Ketiga, ciri yang terakhir ialah kuatnya keyakinan kaum radikalis akan kebenaran program atau ideologi yang mereka bawa. Sikap ini pada saat yang sama dibarengi dengan penafikan kebenaran sistem lain yang akan diganti. Dalam gerakan sosial, keyakinan tentang kebenaran program atau filosofi sering dikombinasikan dengan cara-cara pencapaian yang mengatasnamakan nilai-nilai ideal seperti "kerakyatan" atau "kemanusiaan". ${ }^{12}$ Pada kondisi demikian, dialektika kekerasan dan anti-kekerasan mengalami guncangan luar bisaa. Ketegangan antara tesis dan antitesis dalam dialektika tersebut mencapai puncaknya.

Dalam konteks keagamaan, nampaknya istilah radikalisme hingga kini belum ada kesepakatan mengenai istilah

12 Ibid., h. xviii. Dalam konteks ini, menurut Hassan Hanafi, kekerasan terjadi di lingkungan tertentu ketika ia menjadi satusatunya jalan dan media untuk mengekspresikan eksistensi kemanusiaan. Kekerasan dimulai dari situasi yang terbentuk oleh tiga elemen. Pertama, perasaan mendalam dari individu, kelompok dan bangsa akan ketidakadilan dan keputusasaan; kedua, ketidakberdayaan individu, kelompok dan masyarakat dalam mengubah ketidakadilan tersebut melalui segala cara tanpa kekerasan; ketiga, tidak adanya dialog antara pelaku ketidakadilan dan korbannya, atau mungkin ada namun sekedar dialog semu (bisu). Lihat Hassan Hanafi, Agama, Kekerasan dan Islam yang tepat untuk menggambarkan gerakan radikal. ${ }^{13}$ Oliver Roy dalam bukunya The Failure of Political Islam (1994) menyebut gerakan Islam yang berorientasi pada pemberlakuan syariat Islam sebagai Islam Fundamentalis, yang ditunjukkan dengan gerakan Ikhwanul Muslimin, Hizbut Tahrir, Jami'ati Islami dan Islamic Salvation Front (FIS) ${ }^{14}$ John L. Esposito lebih memilih menggunakan istilah revivalisme Islam atau aktivisme Islam, yang memiliki akar tradisi Islam. ${ }^{15}$ Sementara itu. Muhammad Abid Al-Jabiri menggunakan istilah ekstremisme Islam. Kelompok Islam ekstrem biasanya mengarahkan permusuhan dan perlawanannya kepada gerakan-gerakan Islam "tengah" atau "moderat". Karena itu, Al-Jabiri menyebutkan bahwa musuh sejati Islam ekstrem adalah Islam moderat. Al-Jabiri menunjukkan perbedaan dari gerakan Islam ekstrem di masa kontemporer ini. Gerakan-gerakan

Kontemporer, terj. Ahmad Najib

(Yogyakarta: Jendela, 2001), h. 54.

${ }^{13}$ Banyak ilmuwan yang menyamakan istilah radikalisme agama dengan fundamentalisme (ushûliyyûn), "kaum Islamis" (islâmiyyûn), "kaum otentik atau asli" (ashliyyûn), "pengikut para sahabat utama (salafiyyûn), "militant" atau bahkan "neo-fundamentalisme", karena memiliki kemiripan-kemiripan tertentu yang menyerupai ciri-ciri dalam radikalisme. Dr. Azyumardi Azra, Pergolakan Politik Islam...., op. cit., h. 109.

14 Oliver Roy. The Failure of Political Islam (London: I.B. Tauris \& Co. Ltd., 1994), h. 2-4.

15 John L. Esposito, The Islamic Threat Myth or Reality? (Oxford: Oxford University Press, 1992), h. 7-8. 
ekstemis masa lalu mempraktikkan ekstremisme pada tatanan akidah, sedangkan gerakan-gerakan ekstrem kontemporer menjalankannya pada tataran syariah dengan melawan mazhab-mazhab moderat. ${ }^{16}$

Untuk lebih memperjelas fenomena radikalisme agama, kerangka yang diberikan sosiolog agama, Martin E. Marty, dengan beberapa modifikasi, agaknya cukup relevan diterapkan untuk melihat gejala "kekerasan atas nama agama". Menurutnya, ciri yang utama adalah oppositionalism (paham perlawanan), yakni paham perlawanan terhadap ancaman yang dipandang membahayakan eksistensi agamanya, apakah dalam bentuk modernitas atau modernisme, sekularisasi, dan tata nilai Barat pada umumnya. ${ }^{17}$ Sikap melawan atau berjuang (fight) dilakukan, di antaranya dengan melawan kembali (fight back) kelompok yang mengancam keberadaan atau identitas yang menjadi tatanan hidup; berjuang untuk (fight for) menegakkan cita-cita yang meliputi persoalan hidup secara umum, seperti keluarga atau institusi sosial; berjuang dengan (fight with) kerangka nilai atau identitas tertentu yang berasal dari warisan masa lalu maupun kontruksi yang baru; berjuang melawan (fight againt) musuh-musuh tertentu yang muncul

${ }^{16}$ Muhammad Abid Al-Jabiri, Agama, Negara dan Penerapan Syariah, terj. (Yogyakarta: Fajar Pustaka, 2001), h. 139-149. dalam bentuk komunitas atau tata sosial keagamaan yang dipandang menyimpang; dan terakhir, mereka melakukannya dalam kerangka perjuangan atas nama (fight under) Tuhan. ${ }^{18}$

Dalam hal ini, ormas-ormas Islam yang menentang pembangunan sejumlah rumah ibadah umat Kristiani di sebagian besar daerah Kabupaten Bekasi, seperti Pelajar Islam (PII), Gerakan Pemuda Islam Indonesia (GPII), Front Pembela Islam (FPI), Front Hizbullah, Forum Komunikasi Antar Masjid Indonesia (FORKAMI) dan Ikatan-ikatan remaja masjid yang ada di seluruh Kabupaten Bekasi, memiliki ciri-ciri yang dikemukakan Marty. Pertama, melawan ancaman yang dipandang membahayakan eksistensi agamanya, seperti industrialisasi yang dianggap memiliki misi tersembunyi (hidden agenda) melaksanakan program kristenisasi. Kedua, melawan kembali (fight back) kelompok yang mengancam keberadaan atau identitas yang menjadi tatanan hidup, dalam hal ini kebijakan pemerintah daerah tentang pembangunan rumah ibadah dan kalangan investor asing. Hal ini terkait dengan adanya dugaan rekayasa politik dari partai politik besar tertentu dan aparat keamanan; bertentangan dengan

17 Dr. Azyumardi Azra, Pergolakan Politik Islam...., op. cit., h. 109.

${ }^{18}$ Bahtiar Effendi dan Hendro Prasetyo, op. cit., h. xix. 
Surat Keputusan Bersama (SKB) dua menteri yang mengatur tentang persyaratan pembangunan rumah ibadah sekurang-kurangnya memiliki kepala keluarga (KK) sebanyak 90 KK.; adanya pelanggaran izin membangun bangunan (IMB). Ketiga, berjuang untuk (fight for) menegakkan cita-cita yang meliputi persoalan hidup secara umum, seperti keluarga atau institusi sosial melalui pelembagaan kembali organisasi kemasyarakatan "paramiliter", seperti Ikatan Poetra Daerah (IKAPOED) dan Persatuan Orang Betawi (POB), sebagai "gerombolan preman" yang berfungsi sebagai kelompok penekan. Keempat, berjuang dengan (fight with) kerangka nilai atau identitas tertentu yang berasal dari warisan masa lalu maupun kontruksi yang baru. Kelima, berjuang melawan (fight againt) musuh-musuh tertentu yang muncul dalam bentuk komunitas atau tata sosial keagamaan yang dipandang menyimpang. Perlawanan ini dilakukan kepada kelompok-kelompok yang lebih moderat dalam melihat dan mencermati permasalahan ini. Dan keenam, mereka melakukannya dalam kerangka perjuangan atas nama (fight under) Tuhan. Dengan semangat yang kurang didasarkan pada pemahaman yang komprehensif tentang Islam sebagai sebuah ajaran yang kaffah, mereka seringkali menggunakan cara-cara kekerasan dengan mengatasnamakan untuk menjaga dan memurnikan Islam dari segala bentuk penyimpangan di kalangan umat Islam itu sendiri dan serangan dari agama lain.

\section{Epilog}

Sebagai daerah yang kuat memegang nilai-nilai keagamaan, Kabupaten Bekasi telah menjalankan nuansa agamis bagi aparatur dalam menjalankan pemerintahan yang baik (good governance) dan tidak koruptif dalam merancang dan mengimplementasikan pelayanan, pemberdayaan masarakat, pengaturan dan pembangunan sarana publik. Penekanan nilai-nilai keagamaan dalam segala aspek pembangunan tampak jelas dalam 7 (tujuh) misi Kabupaten Bekasi, salah satunya adalah "Meningkatkan Peran Serta Institusi Keagamaan Dalam Pembangunan Di Segala Bidang".

Hal ini terlihat dari jumlah penduduk muslim di Kabupaten Bekasi Tahun 2009 yang berjumlah 1.949.913 jiwa dari total jumlah penduduk 2,6 juta. Dengan jumlah 7 (tujuh) kawasan raksasa industri, Kabupaten Bekasi adalah daerah penyangga ibukota negara yang sedang mengalami perubahan yang pesat dari pola kehidupan masyarakat agraris menuju masyarakat industri. Bahkan perubahan ini pun menjadikan daerah tersebut sebagai wadah peleburan (melting pot) berbagai etnis ras dan agama. Secara kultur keagamaan, realitas keagamaan masyarakat Muslim 
Kabupaten Bekasi dikenal sebagai masyarakat yang kuat memegang nilainilai keagamaan. Tradisi keagamaan seperti pengajian rutin majelis ta'lim, ceramah agama, tahlil, shalawat dan ratiban, tetap dipegang sebagai nilai-nilai keagamaan yang telah berjalan sejak lama.

Secara kuantitatif, sarana ibadah bagi masyarakat Muslim di Kabupaten Bekasi memang mengalami peningkatan sarana ibadah. Namun, peningkatan kuantitas sarana ibadah dan jamaah haji tampaknya kurang dibarengi dengan peningkatan kualitas pemahaman keagamaan. Bahkan tak jarang, peningkatan sarana ibadah dan jamaah haji ini pun cenderung melestarikan "menjauhnya" nilai-nilai Islam. Artinya ajaran Islam rahmatan lil 'alamîn belum terejawentahkan dalam kehidupan sehari-hari.

$\begin{array}{lrr}\text { Nilai-nilai } & \text { pluralisme } & \text { yang } \\ \text { terkejawantahkan } & \text { dalam } & \text { sikap } \\ \text { keberagamaan } & \text { masyarakat } & \text { Muslim }\end{array}$

Bekasi pada dasarnya tampak cukup terekspresikan dengan baik. Ini bisa disimpulkan dari minimnya peristiwa gesekan SARA yang terjadi jika dibandingkan dengan banyaknya peluang yang tercipta akibat intensitas kemajemukan dan interaksi. Pluralisme masyarakat Muslim Bekasi juga tercermin dari tingkat pengetahuan mereka tentang pentingnya maksud dan tujuan dai toleransi dan kerukunan umat beragama bagi kemaslahatan kehidupan umum di sekitar.Namun, sikap pluralisme ini ternyata masih dalam tataran yang dangkal dan di permukaan saja (superficial) sehingga masih sangat tergantung pada situasi dan kondisi keharmonisan secara umum yang sewaktu-waktu bisa berubah menjadi konflik ketika issu-issu bermuatan SARA beredar secara massif.

Ke-superficial-an pluralisme ini menyebabkan masyarakat Muslim Kabupaten Bekasi terjerembab ke dalam pemahaman dan sikap radikalisme. Mereka masih terikat kuat dengan simbolisme dan sentimen SARA. Jika berhadapan dengan atribut-atribut etnis dan ideologis provokatif, potensi radikalisme pun akan dengan mudah tersulut.

\section{Daftar Pustaka}

Azra, Azyumardi, Pergolakan Politik

Islam: Dari Fundamentalisme,

Modernisme hingga

Postmodernisme (Jakarta:

Paramadina, 1996)

Badan Pusat Statistik (BPS) Kabupaten

Bekasi Tahun 2001.

Badan Pusat Statistik (BPS) Kabupaten

Bekasi Tahun 2001.

Badan Pusat Statistik (BPS) Kabupaten

Bekasi, 2007

Badan Pusat Statistik Kabupaten Bekasi, 2010 
Badan Pusat Statistik Kabupaten Bekasi,

Bekasi dalam Angka 2015,

(Bekasi, BPS, 2015)

BPS, "Indeks Kepadatan Penduduk",

Sistem Informasi Rujukan

Statistik, di tautan

https://sirusa.bps.go.id, diakses

tanggal 15 Oktober 2016

BPS, "Penduduk menurut Wilayah dan

Agama yang Dianut: Provinsi

Jawa Barat", Sensus Penduduk

2010, di tautan

http://sp2010.bps.go.id/index.php/

site/tabel?tid $=321 \&$ wid $=32000000$

$\underline{00}$

"Demo Gereja Santa Clara Bekasi,

Ratusan Elemen Masyarakat

Geruduk Walikota Bekasi", VOA-

Islam, 11 Agustus 2015, di tautan

http://www.voa-

islam.com/read/indonesiana/2015

/08/10/38491/demo-gereja-santa-

clara-bekasi-ratusan-elemen-

masyarakat-geruduk-

walikota.dpbs

Effendi, Bahtiar, dan Prasetyo, Hendro,

Radikalisme Agama (Jakarta:

PPIM-IAIN, 1998)

Effendi, Bahtiar, Repolitisasi Islam:

Pernahkah Islam Berhenti

Berpolitik?, (Bandung: Mizan, 2000)

Esposito, John L., The Islamic Threat

Myth or Reality? (Oxford: Oxford

University Press, 1992)
Hamludin, "Ormas Islam dan Jemaat HKPB Bentrok", Tempo Interaktif, 01 gustus 2010, di tautan https://m.tempo.co/read/news/201 0/08/01/064267876/ormas-islamdan-jemaat-hkbp-bekasi-bentrok

Hanafi, Hassan, Agama, Kekerasan dan Islam Kontemporer, terj. Ahmad Najib (Yogyakarta: Jendela, 2001)

Hidayat, Komaruddin, Tragedi Raja

Midas: Moralitas Agama dan

Krisis Modernisme (Jakarta:

Paramadina, 1998)

Ifzanul, "Masyarakat Tradisional,

Masyarakat Transisi, Masyarakat

Modern, masyarakat Pedesaan

dan Masyarakat

Perkotaan", Jurnal Sosial, 1: 01

(2009)

Al-Jabiri, Muhammad Abid, Agama, Negara dan Penerapan Syariah, terj. (Yogyakarta: Fajar Pustaka, 2001)

J.B. Banawiratma, SJ., "Bersama

Saudara-Saudari Beriman Lain:

Perspektif Gereja Katolik", dalam

Dialog: Kritik dan Identitas Agama

(Yogyakarta: Dian Interfidei, 1993), h. 17.

KBBI Web, "Kamus Besar Bahasa Indonesia Online", di tautan

http://kbbi.web.id/transisi.

Kelompok Kerja Penyuluh Agama

(POKJALUH) Kementerian

Agama Kabupaten Bekasi, 2010 
Koentjoroningrat, Manusia dan

kebudayaan di Indonesia,

(Jakarta : Djambatan, 2010)

Landis, Judson R., Sociology: Concepts and Characteristics, (Belmont:

Wadsworth, 1983)

Mufadillah, Ahmad Haris, "Arti

Pluralisme", Ahmuf, 18 Mei 2011,

di tautan

http://ahmufadillah.blogspot.co.id/

2011/05/arti-pluralisme.html

Muhadjir,Noeng, Metodologi Penelitian

Kualitatif: Pendekatan Positivistik, Rasionalistik, Phenomenologik, dan Realisme Metaphisik, Telaah

Studi Teks dan Penelitian Agama

(Yogyakarta: Rake Sarasin, 1998)

MUI, Himpunan fatwa MUI Sejak 1975,

(Jakarta: Erlangga, 2011), hal.

103

Munawar-Rachman, Budhy, Ensiklopedi

Nurcholish Madjid, Jld. I (Jakarta:

Paramadina-Mizan-CSL, 2006)

Pahmi, Perspektif Baru Antropologi

Pedesaan, (Jakarta : Gaung

Persada Pres., 2010)

Pruitt, Dean G, dan Rubin, Jeffrey Z.,

Teori Konflik Sosial, terj.Helly P.

Soetjipto dan Sri Mulyantini

Soetjipto (Yogyakarta: Pustaka

Pelajar, 2004)

Rachman, Budhy Munawar, Ensiklopedi

Nurcholish Madjid, Jld. I (Jakarta:

Paramadina-Mizan-CSL, 2006)
Rencana Pembangunan Jangka Panjang Daerah Kabupaten Bekasi Tahun 2005-2010

Roy, Oliver. The Failure of Political Islam (London: I.B. Tauris\& Co. Ltd., 1994)

Suaedy, Ahmad, (ed.), Kekerasan dalam Perspektif Pesantren, (Jakarta: Grasindo-P3M, 2000).

Suhanadji dan Waspodo TS, Modernisasi Dan Globalisasi: Studi Pembangunan Dalam Perspektif Global, (Malang : Insan Cendikia, 2004)

Tebba, Sudirman, Islam Pasca Orde Baru (Yogyakarta: Tiara Wacana, 2001)

Webster's Online, "Pluralism", Merriam-Webster, di tautan https://www.merriamwebster.com/dictionary/plural ism 